\title{
Intercultural competency development through a study abroad program
}

\author{
Hsu, Tsu-Chia, Julia $\bowtie$ \\ Lunghwa University of Science and Technology, Taiwan (hsuinhk@mail.lhu.edu.tw)
}

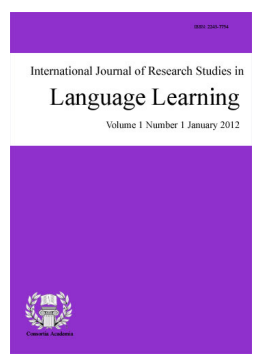

ISSN: 2243-7754

Accepted: 20 November 2013 Online ISSN: 2243-7762

OPEN ACCESS

\begin{abstract}
Recently, more and more universities are focusing on short-term study abroad programs. However, the actual advantages of such programs have not yet been empirically tested. The primary purpose of this study is to investigate whether such study abroad programs can influence participants and improve an individual's intercultural competence. Using both reflections found in journals and follow-up interviews, the study aims to reflect the key factors that contribute to the intercultural development of the study participants. This paper elicits and examines the students' study abroad experiences, particularly in the minimal impacts on the levels of intercultural competence and results of the 2011 summer study abroad program. It is hoped that future study abroad programs will find that this new approach can not only help college students learn better but that it will also shed light on the importance of intercultural competence through dialogue. Further studies are recommended with respect to the duration of the study abroad programs and the quantity/quality of the various activities involved in the enhancement of the students' intercultural competence.
\end{abstract}

Keywords: study abroad; college students; globalization; cultural awareness; intercultural competence; higher education 


\section{Intercultural competency development through a study abroad program}

\section{Introduction}

In Taiwan, internationalization at a university level is accomplished in two ways. First, there is the attraction of international students to study in Taiwan, while the second is found the outgoing Taiwan students either on short-term or degree-seeking programs (Chin \& Ching, 2009). In recent years, higher education in the world is increasingly focusing on short-term study abroad programs for in-service teachers and students. The growing number of students in Taiwan attending study abroad program is said to be caused by their perceived marked up market value brought forth by having an international education experience (Kitsantas \& Meyers, 2001). A majority of the graduating students have pointed out that the chance of landing a job immediately after graduation seems to be higher when they include study abroad as part of their past experience. Therefore, most higher education institutions in Taiwan have opened up partnerships with various international universities not only in the United States, the United Kingdom, and Europe, but as well as with Asian universities.

Study abroad programs are actually considered to be a paradigm shift from the normal classroom blackboard and chalk sessions to something closer to real-life learning programs (Levy, 2003). For many public and private higher universities, a study abroad program contributes to the establishment of friendship and professional ties. Furthermore, studying abroad can also help college students enhance their intercultural communication through the application of a foreign language within a learning environment. Hence, a study abroad program is able to create the long lasting bonds of friendship that promotes sharing common educational and cultural principles (Byram, 2000). This enables both institutions to transcend barriers in order to promote cultural understanding, learning, and cooperation to provide additional opportunities in gaining global perspective through effective communication processes. However, the actual advantages of short-term study abroad programs have not yet been empirically tested. In light of this, the current paper presents the results of a short-term United States (US) summer study abroad program accomplished in 2011. Through the use of the learners' self-reflection diaries, various study abroad factors that contribute to the intercultural competence development of students have been analyzed. It is noted that understanding the benefits of study abroad experience, would contribute to building up the necessary skills to interact with people who are different and in essence, help develop students to become more globally competitive.

Hence, the purpose of this study is to analyze whether the individual's intercultural competence is enhanced by the participation in a short-term, faculty-led summer study abroad program. In a way, the current study seeks for conferring the benefits of gaining international experience with regards to fostering students' intercultural competence from their experience of a study abroad program. More importantly, it judges whether the short-term study abroad activities were effective for the participants.

\section{Literature reviews}

In recent years, increasing numbers of college students prefer to participate in study abroad educational programs rather than studying in their home country (Freed, 1998). Study abroad programs are defined as an "all educational programs that take place outside the geographical boundaries of the country of origin" (Kitsantas \& Meyers, 2001, p. 4). Many researches indicated the fruitful language learning brought forth in study abroad programs (Brecht, Davidson, \& Ginsberg, 1995; DeKeyser, 1991; Freed, 1995; Harley \& Hart, 2002; Lafford, 1995; Lapkin, Hart, \& Swain, 1995; Segalowitz \& Freed, 2004). With regard to English as a Foreign Language (EFL) learners, study abroad opportunity could provide the routine exposure of a foreign language learning environment and attain more opportunities in using foreign language by encountering students' many native speakers (Segalowitz \& Freed, 2004). 
In so doing, students who study abroad are able to develop both language skills and long lasting friendships (Dong, Day, \& Collaco, 2008); more importantly, students can become more competitive in the job market and gain greater success in life (Kitsantas \& Meyers, 2001). Student participants indicate that an internationalized education (more importantly study abroad, contact with international students, and an internationalized curriculum) help develop their intercultural competence. In sum, the provision of study abroad programs becomes a crucial strategy in order to enhance students' intercultural competence (Sinicrope, Norris, \& Watanabe, 2007), and it is hoped to better understand students' mind concepts through the intercultural learning program.

Byram (1997) defines intercultural competence as "the ability to see relationships between different cultures - both internal and external to a society and to mediate, which is to interpret in each other terms, either for themselves or for other people" (p. 12). It also encompasses the ability to critically understand that one's own and other cultures perspective is culturally determined rather than naturally formed. Intercultural communicative competence is viewed as to comprise in two areas: intercultural communication awareness and intercultural communication sensitivity (Chen \& Starosta, 2000). Intercultural communication awareness lays a good foundation for intercultural communication sensitivity; one could not develop a good ICC without either of the above (Byram, 2000). In essence, intercultural competence in itself shows the ability to recognize, respect, value and use productively cultural conditions and orientation patterns with respect to interpreting and shaping the world. Intercultural competence of an individual can actually be used to measure or evaluate the outcomes of study abroad programs (Marx \& Moss, 2011; Parsons, 2010).

In a study abroad program, wherein pre-service student teachers took a semester-long teacher education program in London aimed at confronting the students' ethnocentric worldviews. Results show that by introducing and guiding how culture influences teaching and learning, student teachers were able to develop their intercultural competence (Marx \& Moss, 2011). Hence, the emersion in both cultural and instructional contexts tends to promote positive integration. In addition, Parsons (2010) conducted a study to determine the benefit of university internationalization; results from 1,302 student participants indicate that an internationalized education (more importantly study abroad, contact with international students, and an internationalized curriculum) helps develop students' intercultural competence. Hence, this study seeks to answer the following questions:

$>$ What are the benefits of a short-term study abroad program with regard to the students' intercultural competence?

$>$ What are the other issues brought about by short-term study abroad programs?

$>$ How effective are the short-term study abroad activities?

\section{Methodology}

\subsection{The Participants}

The Learners - The participants of the study consisted of undergraduate and graduate students, coming from the day and evening class session program of a technical and vocational university in northern Taiwan. A total of seventeen $(n=17)$ students, including twelve females and five males, participated in a four-week long study abroad program in one of universities around the mid-west area of the states. Students' ages ranged from 19 to 28 , with a mean of 21 years old. The study primarily focused on developing an individual's intercultural competence within intercultural communication settings. As for increasing interactions with people from a different cultural milieu, the individuals needed to be aware of intercultural sensitivity based on one's cognitive, affective and behavioral aspects (Dong et al., 2008). The duration of the short-term overseas program was four weeks.

The Teachers - Within this program, there were two female language teachers who were native speakers 
teaching during classes and facilitating the seventeen participants joining various on and off campus activities. In addition, two American college students (i.e. one male and the other female) served as program assistants and helped participants in transportation and accompanied them to visit scenic sights in-and-out of the city. More so, there were two other program coordinators on spot or each side of sister universities who were responsible for the completion of the summer program. One of the two coordinators accompanied all college students from Taiwan and served as the custodian and mentor through this overseas summer study program; the other one representing the host university was in charge of the entire program, and she preliminarily planned the study abroad program and contacted all helpers, including the language teachers and assistants. Throughout the entire program, these very two important figures worked hand in hand, including the daily program schedule checked before the day and dealing with crisis management if possible.

The Observer - The observer, who also served as the program coordinator and accompanied all participants in the program, was the researcher. In order to achieve the goal required triangulation of multiple methods, data sources, and individual's viewpoints. The researcher not only documented all participants' thoughts and feedback regarding everyday school activities within four weeks, but she also served as the custodian of careful observation for better understanding the students' needs with regard to both cultural and linguistic knowledge.

The Procedures - In terms of producing a record of each individual's intercultural competence, a qualitative approach is possible and in fact desirable. Using the methods of a self-reflection diary, focus group interviews, and observation served as a basis for analyzing the result of the study. Each individual's diary facilitated his/ her own involvement in planning, reflecting upon and assessing one's daily learning process and progress; it also encouraged the learner to state what he/ she could do in one's writing, including information on language learning and cultural experiences gained through in-and-out of class activities. The study abroad program was organized to promote the participants' overseas learning experiences, and further understood individual's intercultural understanding through interaction.

The self-reflection diary was to help students reflect on what they learned related to the process of cultural and language learning environment. It might consist of the format, which reflected the definition of intercultural competence. After one-month's return from the program, the researcher collected the sojourners' point of view through focus groups, and encouraged follow-up interviews (Allen \& Herron, 2003; Murphy-Lejeune, 2003), diaries (Callen, 1999; Dueñas-Tancred \& Weber-Newth, 1995; Lewis \& Stickler, 2000); (Wagner \& Magistrale, 1999; Warden, Lapkin, Swain, \& Hart, 1995) and other different self-report contact (Pellegrino, 1998); these were employed much more frequently by the researcher with the evaluation of study abroad learning.

On top of it, three out of seventeen participants voluntarily did follow-up interviews after two summers. These indeed captured some crucial information that helped future summer study abroad programs to enhance the program quality; and furthermore, it could help researchers better understand sojourners' great challenges and/ or changes after the study abroad program.

\section{Results and discussion}

This section presents and discusses the results of the qualitative data, including the student's diaries as well as the post-sojourn debriefing sessions. Students' portfolios not only revealed individual rich evidence concerning personal growth between the host culture and one's own culture, but also enabled students to bridge the gap between the differences through reflecting on their study results.

The following analysis fully reviewed all data developing individual cultural perception's in order to fully discover students' potential competency concerning intercultural interaction during the sojourn, discover intercultural potential, promote the development of culture, enrich individual vision, and promote two sides of cultural harmony through diversity activities brought by the study abroad program. In the following, research questions are followed by answers. 
$4.1 \mathrm{RQ}$ 1: What are the benefits of a short-term study abroad program with regards to the students' intercultural competence?

\section{Attitudes: Interest in other people's way of life}

The section discussed the participants' experience of enjoyment during the study abroad program, which eventually led to positive attitudes toward their learning environment. Student B stated concerning her curiosity and openness, readiness to suspend disbelief toward cultural learning and her belief developed by experiencing the study abroad program:

It is my first time to experience the whole English teaching taught by foreign teachers. It is so cool! Though there was something we don't understand, we all listened together and figured out the meaning and then we did the translation together. In so doing, we got to become more familiar with one another in class (B-2011, day $2 \log$ )

Here we could see that student B and like many others in the study abroad program found the whole English learning environment very interesting and enjoyed the group work and activities. By implication, students interacted with one another through group work with a great deal of enjoyment.

Another good example also relates to the same concept:

When we had a dialogue with people here, they talked to us with a great deal of patience. In our class, we would help one another, and that made us feel great (G-2011, day $1 \mathrm{log}$ )

In this quotation, student $\mathrm{G}$ enjoyed talking to people and shares her learning experiences with others. This development allowed her to have a positive feeling toward the foreign language learning situation.

In addition, the following male student also showed his positive learning attitudes. In particular, he enjoyed the study abroad program through the different kind of activities as follows:

After dinner, we went downtown and watched an outdoor movie. We were seated on the lawn and enjoyed the movie with popcorns, what a wonderful experience (O-2011, day $16 \log )$

In this case, student $\mathrm{O}$ found himself enjoying the social activity with his classmates. He could engage in the outdoor movie and experienced a meaningful and authentic event.

The following quote from another student highlights the interaction enjoyment, and also demonstrates different kinds of activities through which students learned to play a Mahjong game:

We met three foreigners, Amy, DK, and Arab, in the dorm, and we taught them how to play a Mahjong game. Yet, we felt dumbfounded. We found that they were so smart so that their attitude towards the game couldn't be controlled while playing the game. All in all, it's interesting to teach them how to play a Mahjong game (M-2011, day $13 \log )$

In order to interact with foreigners, student $\mathrm{M}$ taught others how to play the Mahjong game. While doing so, he felt very happy about it. Hence, playing typical Chinese oriented games such as, Mahjong is a kind of activities that is able to help students practice their individual social skill within a group.

Another similar situation is stated as follows:

It was an eye opener for me in Niagara Falls. Besides, it's interesting to go there with foreigners, and we talked about cultural difference to one another on the way in the school bus. Today we had friends from Turkey, the Middle East, and Arabs, and it's very interesting for me to see them along with us for an outing (J-2011, day $4 \log$ ) 
Student $\mathrm{J}$ reflected that she felt great not only to see Niagara Falls but also enjoys talking about the cultural difference with her foreign friends. From this excursion to Niagara Falls, students enjoyed interacting with people from difference cultures brought about by the different kind of social events.

Last but not the least; the following example is a typical cultural event:

We went to Cynthia brother's house, and we roasted meat, played game, and bounced on the bed, it was really funny (J-2011, day $7 \mathrm{log})$

This quote suggests that student $\mathrm{J}$ participated in the social event; BBQ, and she felt that the social event was very amusing, which provides a good opportunity to interact with one another.

\section{Skills of interpreting and relating: Ability to change perspective (interaction attentiveness)}

By experiencing the study abroad program, students enrolled in the study abroad program have realized that they gradually understood other cultures by seeing things from a different point of view and by looking at their own culture from that perspective. For instance:

I watched Mother-daughter interaction between Diane and Jane; especially that Jane taught Diane how to dance. It's important for people to social with one another in the states, such as greetings, communicating to others and responding to different individual. People in the states are truly different from us. For example, it's interesting to see Jane greeting to her family senior people and Jane's parents socializing with Jane's friends in the party. (F-2011, day14 log)

Student $\mathrm{F}$ who studied abroad realized that her culture is different from the host culture by seeing things from a different point of view. For example, the mother-daughter relationship between her teacher, Diane, and Diane's daughter, Jane, seemed like friends to each other. Jane would teach Diane how to dance with her friends. More so, Jane naturally greeted to family friends, especially her grandparents in the party before her friends, and treated everyone as close as one of her family friends. By implication, student F saw things differently and could put herself in other's shoes to change her perspective by viewing things differently in the host culture.

The following quote from another student highlights the interaction attentiveness, and also demonstrates different kinds of activities through which students learned to play a Mahjong game:

After the snap going to Bl for supper, I saw Amanda teaching some Arabian students Mahjong (Chinese board game). How funny it is! Three out of four players were foreigners, and they indeed were too smart not to play game with us. (C-2011, day13 log)

In this quotation, student $\mathrm{C}$ attentively noticed that other foreign students would feel interested in immersing in our culture by learning playing Mahjong with us students. This development allowed her to have a positive feeling toward accepting change by seeing things in someone's shoes.

And:

Tonight I saw teacher Nichole teaching her children... Nichole's oldest son's very responsible. For example, he would call either brother to separate while his siblings arguing to one another. I found that they call each other's name instead of brothers or sisters. In so doing, the way siblings calling ones' names is quite different from the way we call brothers or sisters. However, saying goodbye to everyone before going home is the same as we do. (F-2011, day21 log)

Student F reflected that Nichol's oldest son had abilities to help his mother, Nichole, take care of other siblings by separating his other brothers while those two younger brothers did wrong things, not fighting with them. Besides, the student also noticed cultural differences by siblings calling each other by their own names in the host culture, and not calling each other brother or sister. In so doing, she could identify her family different from 
the host family in interpreting and relating to the cultural difference while studying abroad.

And:

We went to visit a church full of artistic atmosphere this afternoon. I was glad that we could see a very westernized church, and the pastor elaborately introduced us about some stories of Jesus Christ. I was truly happy to hear that. (E-2011, day18 log)

In this case, student E happily understood Christianity as a religion by hearing the pastor's briefing about the church. . This visit allowed her to have a positive feeling toward the cultural learning experience.

\section{Skills of discovery and interaction: Ability to cope with living in a different culture (Respect for cultural differences)}

In order to understand the various underlying factors with regards to IC, the following representing evidences from students' logs are given. In the summer camp, students undertake different speaking assignments and various in-and-out of campus activities. The following section depicts the qualitative evidence with regards to cope with a range of reactions one had to living in a different culture (euphoria, homesickness, physical and mental discomfort and many others) within the study abroad program. In the following, the individual noticed that her religion is different from others while studying abroad so that she treated other religion as an asset:

In this case, student $\mathrm{G}$ recognized that her religion is different from others during the summer camp. Yet, she acknowledged the cultural difference, and, furthermore, accepted and appreciated the religious difference between individuals'.

I am a Buddhist. I believe that every religion has its special story and belief, so I respect every religion (G-2011, day $19 \log$ )

Another student $\mathrm{F}$ also echoed a similar notion between before and after the study abroad experience, which is as follows:

There is a special cultural factor in America - that is respect. For example, Amy is a school friend of the study abroad students and she is a Pilipino American student in YSU. She seemed to show her high respect for her professor while we visited her lab (F-2011, day $12 \log )$

Student F felt one distinct aspect of American culture, which is respect. She noticed that teachers and students treat each other like friends. Although, they called each other by their first name, there still exists a sense of respect among them. Unlike in Taiwan (as with typical Chinese society); besides the respect between teachers and students, there still exists a hierarchy on addressing someone, such as with employers and employees, parents and children, and the like.

Student $\mathrm{H}$ had a similar experience with that of student $\mathrm{F}$ :

...watching the interaction between teacher Diane and her daughter, and the daughter taught her mom how to dance. In the states, social is one of important things and it is truly a different culture in America from us Taiwan, such as the ways of greetings and communicating to one another. It is interesting to see the daughters greeting to the senior family members and watch the parents playing with their children's classmates (F-2011, day $14 \mathrm{log}$ )

Student $\mathrm{H}$ found some other interesting intercultural factors among people within a social environment. For example, teacher Diane's daughter taught her mother how to dance and played together with Diane's classmates in the social activity. Student $\mathrm{H}$ seems to have a deep thought about the relationship between mother and daughter, and also appreciating this mother-daughter interaction. Thus, respect for cultural difference plays a crucial key role to allow student $\mathrm{H}$ to accept and appreciate the difference between the host and her own culture. 
By implication, there is a positive interaction among the relationship between mother and daughter and the relationship between the senior family members and children.

In the next case, student $\mathrm{L}$ could tell to what extent her views toward respect for cultural difference had developed.

Before I came to the states, I thought that they (Americans) were not enthusiastic and compassionate, but I was wrong after I realized the truth. They (Americans) would greet you anytime; however, we would not do the same thing in Taiwan (L-2011, FG)

Student L responded that she feels rather positive towards cultural differences during study abroad. More so, she accepted the cultural differences and came to appreciate and respect how other culture go about with their normal day to day life.

Student M stated an experience similar to that of student L:

... for example, two teachers would show us how to play baseball and teach us what the baseball terminology is and played the baseball videos before we went to the baseball game. Yet, teachers in Taiwan might only write the words on the blackboard and explain to us. It seems abstract to us and we only recite and don't understand what the words mean (M-2011, FG)

Student L observed that the teachers arranged some social activities during the period of the study abroad program and taught students how to employ their knowledge and skills. For example, American teachers during the summer camp would demonstrate how to use baseball vocabulary and skills before watching the game. More importantly, student L stated that the teacher's teaching style in Taiwan is quite different with the American teachers. By implication, the student felt the need to first respect cultural difference, because this is a way to allow the individual to really appreciate and experience cultural differences in a positive way.

\section{Knowledge: Knowledge about another country and culture (interaction engagement)}

By interacting with other students within the program, the individual understood how to engage in conversation with people of the other culture and/ or maintain a conversation. Besides, students could understand some important facts about living in the other culture and about the country, state and people. For instance:
I felt the campus very large on the first day visit. It seemed to me with sort of fear to talk to other people. However, it seemed to me that I could communicate to others if I spoke out. On the country, classmates and teachers tried to engage in conversation. In fact, speaking English seemed not too difficult to talk to one another, but more interesting than what I thought. (J-2011, day $1 \log$ )

On the first day, student $\mathbf{J}$ visited the campus and felt fresh about everything, especially the language. With encouragement from her foreign teachers and classmates, she felt that she could be more brave and confident to speak English more in order to communicate with others. While doing so, she felt she could attentively engage with others in the study abroad program because she found the language not difficult but interesting.

And another student $\mathrm{P}$ had a similar experience with student $\mathrm{J}$ as follows:

I used to school life here after several days in the states. Now I felt relaxed and not to feel tense when I saw foreign friends. (P-2011, day4 log)

Student $\mathrm{P}$ found he gradually accustomed to study life in the new environment after arriving here a few days. Now, he saw friends he was not as nervous as he arrived on the first day. By implication, he developed a positive engagement with others and got used to the study abroad program. 
And:

I love all teachers and classmates. All of them were friendly and funny. I was glad that I had a great experience with everyone here. I would not forget any of them in my life. (E-2011, day23 $\log )$

In the end of this program, student $\mathrm{E}$ found it a great experience with teachers and classmates. By implication, student E seemed to understand people and its culture in the study abroad program so well by saying that 'they were friendly and funny.'

\section{Critical cultural awareness/political education: Knowledge about intercultural communication (interaction confidence)}

This section indicates that whether students knew how to discover new things and/ or new aspects of the other culture for themselves. More so, they knew how to resolve misunderstandings which arise from the individual's lack of awareness of the view point of another culture. For instance:
Some friends and I went to do laundry at BI F of the dormitory. We ran into some campus cops, and we chatted for a long time. They seemed very friendly to us and they introduced themselves to us concerning answered our request about Las Vegas. They seemed compassion while talking to us. (H-2011, day $6 \log )$

Student $\mathrm{H}$ found that he is interested in the cross-cultural environment and tried to discover new things (i.e. traveling to Las Vegas) and new aspects of the host culture for himself. More so, he seemed very confident and willing to overcome the lack of awareness with regard to the new environment by chatting with the campus cops. In the end, he found that the local polices seemed very nice to them and showed compassion to interact with international students. It implied that student $\mathrm{H}$ seemed to show his confidence to present his cultural knowledge by talking to people from the host culture.

In addition, the following student $\mathrm{T}$ also showed her interest regarding intercultural communication. In particular, she was aware of the importance of practicing English through communicating with different people other than her teachers or other students as follows:

It's time again to communicate with some Americans in the dormitory and I loved to practice English! In doing so, I could practice English more and more! The cleaning lady, Jessie, seemed to be one of the best persons to talk to. (Q-2011, day11 log)

In this quotation, student $\mathrm{T}$ enjoyed talking to people and shared her learning experiences with others, including the cleaning lady in the dorm. This development allowed her to have a positive feeling toward the foreign language learning situation. By implication, student $\mathrm{T}$ showed her high motivation and confidence and presented her knowledge of intercultural communication.

Through the study abroad program, most students seemed to develop the ability of intercultural competence by focusing on likely potential factors concerning attitudes, knowledge, skills of interpreting and relating ability, skills of discovery and interaction, respect for cultural difference through the attendance of diverse intercultural activities. More importantly, students learned to be patient and to consult with their teachers during difficult situations, such as finding merchandise for their personal or family needs, learning to appreciate different cultural treasures during the museum visit, meeting difficulties in communicating with others, and many others.

\section{$4.2 \mathrm{RQ} 2:$ What are the other issues brought about by the short-term study abroad programs?}

To better understand the different issues during 2011 of the study abroad groups and discuss the issues in sustaining problems with regards to IC, questions regarding such issues were asked during the focus group sessions. The following shows a list of the other issues and dilemmas about the study abroad program mentioned 
Hsu, T.-C. J.

during the focus group sessions and the students' logs as given below:

I found English very difficult because I am not majoring in Applied Foreign Languages or English department. For example, I wanted to buy something to eat, but I found it difficult to talk to the cashier, because she spoke too fast. In fact, I could hardly understand anything, but some keywords (B-2011, FG)

In order to buy food in the supermarket, student B tried to practice English to communicate with the cashier working in the store. While doing so, she felt very upset about her poor listening and speaking skills. As a matter of fact, she only understood few key words during the dialogue even she tried very hard to follow the speaking path of the native speaker in the store. Yet, she could hardly help but complaining about the native speaker with fast speed because of her helplessness in English conversation.

Another similar situation is stated as follows:

I found processing language skills is indeed more important than anything else. It's because speaking the target language could bridge the gap between different cultures. Without the individual's fluent speaking skills, it is hardly for anyone to communicate with others before knowing the cultural difference (L-2011, FG)

In this case, student L found the key to engage with people across cultures by saying, 'processing language skills is indeed more important than anything else.' Owning good language capacity seems necessary and crucial for one to bridge the gap. Otherwise, he or she found the dialogue difficult to communicate with foreigners.

Another student, I, also echoed a similar notion towards language learning:

I still practiced how to speak English fluently; however, I found it is quite difficult. When I have difficulty in expressing myself, I try to use body language or try to speak some keywords to express how I felt (I-2011, FG)

The respondent I indeed found speaking to be the most difficult of the four skills, and it required practice before obtaining a good speaking skill. If she couldn't express what she really meant, she found the solution by using body language to talk or pinpoint some key words close to the meaning behind the sentence that she could not speak.

Another crucial issue concerning by the respondent $\mathrm{J}$ as given below:

In Taiwan, I met some exchange students from our sister school in America, and I found that they were very nice. I thought that foreigners should be friendly in nature. After I arrived here (America), I found some people seemed very friendly; however, others would discriminate us (J-2011, FG)

In this case, student $\mathbf{J}$ felt a gap before and after the study abroad program with on the issue of the hospitality in the host culture. Before studying abroad, she felt all foreign exchange students are nice and friendly from her acquaintance. However, she changed her perceptions after interacting with people in the host culture. In America, it seemed that some were friendly to her; yet, others would have an impolite attitude towards people across cultures. She regarded such uncomfortable feelings as discrimination towards her cultural differences.

4.3 RQ3: How effective were the short-term study abroad activities?

\section{A Live Baseball Game (Scrappers game)}

... for example, two teachers would show us how to play baseball and teach us what the baseball terminology is and played the baseball videos before we went to the baseball game. Yet, teachers 
in Taiwan might only write the words on the blackboard and explain to us. It seems abstract to us and we only recite and don't understand what the words mean (M-2011, FG)

And:

Teacher Amy taught us singing 'Take me out to the ball game' and we played small games related to baseball rules in class (S-2011, FG)

Student $\mathrm{F}$ felt involved and interested in the class because the teachers taught the participants how to use the words and their meaning while they watched the baseball game. Also student $\mathrm{S}$ could relate to student $\mathrm{F}$ because they were taught how to sing during the baseball game and understand the baseball rules. Students could absorb baseball program related knowledge and apply immediately what they had just learned in a meaningful and authentic event (i.e. Scrapper game). With such activities, students gained more experience in using what they had just learned through practical application.

During the morning class session, most students could learn and understand the concept of baseball and its related terms. Afterwards, the students were brought to a live baseball game and immediately immersed in intercultural interactions. Most students had multiple opportunities to practice their vocabularies, spontaneously joining the commercial activities, or playing musical chairs during the event. In doing so, the participants could better process knowledge about intercultural communication and knowledge about another country and culture, and furthermore feel positive about other people's way of life and ability to change perspective.

\section{Introductions Ice-Breakers}

The first class was doing self-introduction and then we used the first letter of our name to make a sentence. Wow! We finally got to know everyone's English name (T-2011, day 3 log)

In this quotation, student $\mathrm{T}$ was engaged by the introduction class because he finally got to know other classmates' names through the activities.

In addition, the following student also seemed to have similar feelings as the previous student T. In particular, student $\mathrm{F}$ enjoyed the name game as follows:

There was one thing that I needed to mention that we played a funny game about our names. This is really cool. For example, Sam said if your name is Barbara, you needed to make a sentence, such as 'My name is Barbara and I like bowling'. (F-2011, day $3 \log$ )

And:

Today was the first day in class. I woke up and felt very excited to go to class. Indeed I felt different experience while sitting in class here. I felt very relaxed because the teaching and the teacher very funny. While foreign teachers introduced themselves to students, we wouldn't feel nervous at all, but funny. (B-2011, day $3 \log )$

Both student B and F felt interested in the class because the teachers taught them to use their first name initial to make a sentence. In doing so, they not only learned how to listen carefully while other classmates talking, but they also had much fun in class by saying 'we played a funny game about our names.' In particular, student B felt interested throughout the entire lesson, and did not feel any nervousness at all.

\section{Class Conversation Group}

Today it was very funny in class. We had a storytelling activity during morning session. Finally, we all had a great potential with creativity and imagination. (J-2011, day $4 \log )$

In this quotation, student $\mathbf{J}$ enjoyed the storytelling activity during class because she could find all classmates 
enjoying the lesson. It implied that the class conversation activity was very effective by telling a story one after another.

Another student $\mathrm{E}$ had the similar thought as the previous student $\mathrm{J}$ as follows:

After breakfast, we immediately went to the class, and the class was so funny today. Teachers taught us in class to tell the story one by one as a whole. While it was my turn, I told that 'the princess knew the guy was a witch, and she kicked his ass. The teacher laughed it, and it's really fun in class. (E-2011, day $5 \log$ )

In this quotation, student $S$ enjoyed the class because she was immersed in the class atmosphere by telling stories as a group in class. When she told her part of the story, she felt relaxed and fun because her teacher also laughed at it. It implied that the learning atmosphere was very effective because of the students' engagement in the class activity.

And:

....everyone had to tell a sentence, and it had to link the previous sentence concept. I felt this improved my listening skills because I had to admit that I attentively listened to what people talked about and immediately jotted it down. (G-2011, day $5 \log$ )

All in all, almost all students enjoyed the story telling activity because the way the teacher taught was fun and interesting. It implied that such class activities like group storytelling were very effective to most students in the program.

There was another different class activity for engaging students in class conversation as follows:

We additionally played a game, which we needed to target an object, and told the teacher how to get that thing. It was so funny because the teacher played with us. (S-2011, day $8 \log$ )

In this quotation, student $S$ enjoyed the teacher's guidance by providing direction for the teacher to find the target in class. She found it funny because the teacher also played a part while guiding students to speak in class.

Analysis also showed that it is helpful for the participants to spend a short-period of time (i.e. one or two hours) on lessons and then apply immediately what they had just learned in a meaningful and authentic event (i.e. a trip to ride on the roller coasters). With such activities, students gained more experience in using what they have just learned through practical application. For instance, there was the lesson with respect to teachers introducing the history of local baseball game (i.e. Scrappers game). During the morning class session, most students could learn and understand the concept of baseball and other related terms. Afterwards, the students were brought to a live baseball game and immediately immersed in intercultural interactions. Most students had multiple opportunities to practice their vocabularies, spontaneously joining the commercial activities, or playing musical chairs during the event. In doing so, the participants could process better knowledge about intercultural communication and knowledge about another country and culture, and furthermore feel positive in other people's way of life and ability to change perceptive.

As shown in Appendix One; the 2011 study abroad program activities, such as the combination of on-campus (i.e. attending gym activities daily or writing in-class) and off-campus activities (i.e. visiting art galleries and history museums, coach to Niagara Falls, and many others) have produced a positive intervention effect for all the students' intercultural effectiveness towards intercultural competence, such as factors of interest in other people's way of life and ability to cope with living in a different culture. However, additional activities or attention on enhancing knowledge about another country and culture, knowledge about intercultural communication, and ability to change perspective, should be more considered in future study abroad program. 


\section{Discussion}

The above evidences from the findings demonstrated some effective ways to enhance students' intercultural competence through a short-term study abroad program.

In addition, post-departure interviews after the study abroad program, many participants described their previous study abroad experiences two years ago, and revealed interests in a self-independent travel tour in the near future. Eleven out of thirteen female students graduated from the school. Two participants are working in a foreign Airline company: one became a steward; the other serves as Customer Service Advisors at the airport. More so, three have been planning to do working holidays in a long-term period after graduation. The rest of the females had work related to the business and international trade companies. Another two senior students realized that they had a great impact with the group studied abroad in 2011. Other than females, three male participants are now serving in the army after graduation this summer, and the other one has studied the graduate school for one year. Not only did they actively help foreigners by problem solving in using better English language skills in the workplace, but they also gained intercultural cultural knowledge and interpersonal skills preventing from their interactional anxiety to some degree.

Something should be considered to improve the program in the near future. Unlike other short-term study programs, all students in this program lived in the dormitory since the first day they arrived at the school, no host family involved the students except for the BBQ hosted in the teacher's house. Average students reflected that during this program they only socialized with those who lived in the campus or teachers in the program, but they needed to increase their vision by communicating with local families or households under such an intercultural project. In addition, the duration (time or length) factor of the study abroad program might also be a potential limitation factor. Instead of spending the whole week on the tour in the East, the students might be doing some other activities would be rich in interaction (i.e. field trips with tutors or skits with their language teachers). In so doing, students would be able to further strengthen their intercultural competence.

In short, many students processed the ability to bridge the gap between cultures, and presented some degree of intercultural competence. By so doing, this encouraged students to discover local cultural potential to strengthen cross-cultural learning, to develop individual communicative skills, and to enhance their cross cultural understanding and harmony. Through these cultural and creative projects, these students undoubtedly maximized their own intercultural competence.

\section{Conclusion}

Results of the study suggest that such a short-term study abroad program can have a positive impact for student learners on their overall intercultural competence. The main premise of the paper is that such an effective program empowers students' intercultural competence, which leads them towards the respect for different cultures as well as promotes cultural interaction and competency. In addition, individual differences are noted while previously discussing the impact of the study abroad program.

The findings also provide useful evidence to school practitioners and educators, administrators, researchers, and students on the practical effects of joining study abroad programs. In such a study abroad program, practitioners and students are two sides of the coin. Educators can play an important role to guide and lead students to appreciate diverse cultures, and respecting other persons' values, and identities of their cultures with positive attitudes.

Additionally, future researchers need to apply more theories and useful solutions to cope with intercultural issues. The following are some recommendations: first, apply useful activities in enhancing students' intercultural capabilities beyond their cultural perspective. Furthermore, create more innovative intercultural activities to motivate individuals to appreciate cultural differences. Lastly, promote both college faculty and staff in leading such a study abroad program so that both parties in different educational institutions could avail a 
greater benefit and generate a two-way communication platform in terms of reinforcing intercultural competence in higher educational milieu.

\subsection{Suggestions for Future Participants}

With respect to the second research question, first and foremost, researchers from both sides need to conduct a comprehensive and thorough issue analysis of the resolutions. This includes identifying and investigating the stock issues concerning resolutions, such as the nature, inherency and significance of the harm, and the details, solvency, feasibility and disadvantages of the plan. This also means an understanding of what issues to be brought forth on whose initiative, what issues can go hand in hand, and what issues work only independently.

Future studies can provide significant effects on the much needed intercultural communicative competency to become competitive in a diverse and global cultural environment. We need to enhance college students' positive interaction with both a good command of the English language and intercultural competence by developing increasing sound study abroad programs each year. After all, the global world needs to educate more individuals working together with not only good communicative skills but also adequate intercultural competency.

\subsection{Significance of the study}

The significance of the study is mainly focused on the overall goal of enhancing the students' intercultural competence. Furthermore, the current study is able to help students realize what study abroad experiences are able to bring to them, instead of the normal concept of study abroad as solely a shopping and having fun experience. The study further gives grounds that such a study abroad program can also provide significant effects on the much needed competency to become competitive in a multi-culture environment.

\section{References}

Allen, \& Herron. (2003). A mixed-methodology investigation of the linguistic and affective outcomes of summer study abroad. Foreign Language Annals, 36(3), 370-385. http://dx.doi.org/10.1111/j.1944-9720.2003.tb02120.x

Brecht, R., Davidson, D. E., \& Ginsberg, R. B. (1995). Predictors of foreign language gain during study abroad. In B. F. Freed (Ed.), Second language acquisition in a study abroad context (pp. 37-66). Amsterdam: Benjamins.

Byram, M. (1997). Teaching and assessing intercultural communicative competence. Clevedon: Multilingual Matters Limited.

Byram, M. (2000). Assessing intercultural competence in language teaching. Sprongforum, 18(6), 8-13.

Callen, B. (1999). Cross-cultural capability: The student diary as a research tool. In D. Killick \& M. Parry (Eds.), Languages for Cross-Cultural Capability (pp. 241-248). Leeds: Leeds Metropolitan University.

Chen, G. M., \& Starosta, W. J. (2000). The development and validation of the intercultural sensitivity scale. Paper presented at the 86th Annual Meeting of the National Communication Association from http://www.eric.ed.gov/PDFS/ED447525.pdf

Chin, M. C. J., \& Ching, G. S. (2009). Trends and indicators of Taiwan's higher education internationalization. The Asia-Pacific Education Researcher, 18(2), 185-203. http://dx.doi.org/10.3860/taper.v18i2.1322

DeKeyser, R. M. (1991). Foreign language development during a semester abroad. In B. F. Freed (Ed.), Foreign language acquisition and the classroom (pp. 104-118). Lexington, MA: D.C. Heath.

Dong, Q., Day, K. D., \& Collaco, C. (2008). Overcoming ethnocentrism through developing intercultural communication sensitivity and multiculturalism. Human Communication, 11(1), 27-38.

Dueñas-Tancred, M., \& Weber-Newth, I. (1995). Profiling and accrediting the year abroad In G. Parker \& A. Rouxeville (Eds.), 'The Year Abroad': Preparation (pp. 110-126). London: CILT.

Freed, B. F. (1995). What makes us think that students who study abroad become fluent. In B. F. Freed (Ed.), 
Second language acquisition in a study abroad context. Amsterdam: Benjamins.

Freed, B. F. (1998). An overview of issues and research in language learning in a study abroad setting. Frontiers: The Interdisciplinary Journal of Study Abroad, 4(2), 31-60.

Harley, B., \& Hart, D. (2002). Age, aptitude, and second language learning on a bilingual exchange. In P. Robinson (Ed.), Individual differences and instructed language learning (pp. 301-330). Amsterdam: Benjamins.

Kitsantas, A., \& Meyers, J. (2001). Studying abroad: Does it enhance college student cross-cultural awareness. Paper presented at the 2001 Centers for International Business Education and Research Conference. From http://eric.ed.gov/PDFS/ED456648.pdf

Lafford, B. (1995). Getting into, through, and out of a survival situation: A comparison of communicative strategies used by students studying Spanish abroad and at home. In B. F. Freed (Ed.), Second language acquisition in a study abroad context (pp. 97-121). Amsterdam: Benjamins.

Lapkin, S., Hart, D., \& Swain, M. (1995). A Canadian interprovincial exchange: Evaluating the linguistic impact of a three-month stay in Quebec. In B. F. Freed (Ed.), Second language acquisition in a study abroad context (pp. 67-94). Amsterdam: Benjamins.

Levy, J. (2003). Theoretical perspectives on the study abroad site as a location of cultural intersection. Paper presented at the Annual Conference of the Association of Academic Programs in Latin America and the Caribbean. From http://www.aaplac.org/library/LevyJulie03.pdf

Lewis, T., \& Stickler, U. (Eds.). (2000). The Intercultural Project Lancaster.

Marx, H., \& Moss, D. M. (2011). Please mind the culture gap: Intercultural development during a teacher education study abroad program. Journal of Teacher Education, 62(1), 35-47. http://dx.doi.org/10.1177/0022487110381998

Murphy-Lejeune, E. (2003). An experience of interculturality: Student travelers abroad. In G. Alred, M. Byram \& M. Fleming (Eds.), Intercultural Experience and Education (pp. 101-113). Clevedon: Multilingual Matters.

Parsons, R. L. (2010). The effects of an internationalized university experience on domestic students in the United States and Australia. Journal of Studies in International Education, 14(4), 313-334. http://dx.doi.org/10.1177/1028315309331390

Pellegrino, V. (1998). Student perspectives on language learning in a study abroad context. Frontiers: The Interdisciplinary Journal of Study Abroad, IV.

Segalowitz, N., \& Freed, B. F. (2004). Context, contact, and cognition in oral fluency acquisition: Learning Spanish in at home and study abroad contexts. Studies in Second Language Acquisition, 26, 173-199. http://dx.doi.org/10.1017/S0272263104262027

Sinicrope, C., Norris, J., \& Watanabe, Y. (2007). Understanding and assessing intercultural competence: A summary of theory, research, and practice. Second Language Studies, 26(1), 1-58.

Wagner, K., \& Magistrale, T. (1999). Writing across Culture: An Introduction to Study Abroad and the Writing Process. New York: Peter Lang Publishing Co.

Warden, M., Lapkin, S., Swain, M., \& Hart, D. (1995). Adolescent language learners on a three-month exchange: Insights from their diaries. Foreign Language Annals, 28(4), 537-550. http://dx.doi.org/10.1111/j.1944-9720.1995.tb00827.x 
Hsu, T.-C. J.

Appendix

2011 Study Abroad Program of Activities

\begin{tabular}{|c|c|c|c|c|c|c|}
\hline $\begin{array}{c}11 \\
\text { YSU } \\
\text { SUMMER } \\
\text { ARTS } \\
\text { FEST }\end{array}$ & $\begin{array}{c}12 \\
\text { Classes Begun } \\
\text { Introductions } \\
\text { Ice-Breakers } \\
\\
\text { Focus Area: } \\
\text { Student Life }\end{array}$ & $\begin{array}{c}13 \\
\text { Classes } \\
\text { Intro to Camp } \\
\text { Book } \\
\text { Focus Area: } \\
\text { Niagara Falls }\end{array}$ & Niagara Falls & $\begin{array}{c}15 \\
\text { Classes } \\
\text { Conversation } \\
\text { Group } \\
\text { Focus Area: } \\
\text { Museum/Arts } \\
\text { Collection }\end{array}$ & $\begin{array}{c}16 \\
\text { GROVE CITY } \\
\text { SHOPPING } \\
\text { Focus Area: } \\
\text { Cultural } \\
\text { Festivals }\end{array}$ & $\begin{array}{c}17 \\
\text { BBQ\& } \\
\text { Lowellville } \\
\text { Festival }\end{array}$ \\
\hline $\begin{array}{c}18 \\
\text { Southern } \\
\text { Park Mall \& } \\
\text { Shops@ } \\
\text { Boardman } \\
\text { Park }\end{array}$ & $\begin{array}{c}19 \\
\text { PIZZA NIGHT } \\
\text { Focus Area: } \\
\text { Restaurants/Pizz } \\
\text { a }\end{array}$ & $\begin{array}{c}20 \\
\text { Classes } \\
\text { Conversation } \\
\text { Group } \\
\text { Focus Area: } \\
\text { Amusement } \\
\text { Park }\end{array}$ & $\begin{array}{c}21 \\
\text { CEDAR } \\
\text { POINT }\end{array}$ & $\begin{array}{c}22 \\
\text { Classes } \\
\text { Conversation } \\
\text { Group } \\
\text { Focus Area: } \\
\text { Leisure } \\
\text { activities }\end{array}$ & $\begin{array}{c}23 \\
\text { MOONLIGHT } \\
\text { BOWLING } \\
\text { PARTY } \\
\text { Focus Area: } \\
\text { Movies/ } \\
\text { Media }\end{array}$ & $\begin{array}{c}24 \\
\text { Drive in Movie }\end{array}$ \\
\hline $\begin{array}{c}25 \\
\text { Millcreek } \\
\text { PARK } \\
\text { Boating, Hiking } \\
\text { \& BBQ }\end{array}$ & $\begin{array}{c}26 \\
\text { Classes } \\
\text { Conversation } \\
\text { Group } \\
\\
\text { Focus Area: } \\
\text { Sports }\end{array}$ & $\begin{array}{c}27 \\
\text { Scrappers } \\
\text { Game } \\
\\
\text { Focus Area: } \\
\text { American Art }\end{array}$ & $\begin{array}{c}28 \\
\text { Butler } \\
\text { Museum of } \\
\text { American Art }\end{array}$ & $\begin{array}{c}29 \\
\text { Classes } \\
\text { Conversation } \\
\quad \text { Group } \\
\\
\text { Focus Area: } \\
\text { Student Life }\end{array}$ & $\begin{array}{c}30 \\
\text { Meet\& Greet } \\
\text { w/ President }\end{array}$ & $\begin{array}{c}31 \\
\text { Farewell } \\
\text { BBQ@ } \\
\text { Lynn }\end{array}$ \\
\hline
\end{tabular}

